UNIVERSIDADE FEDERAL DO MARANHÃO

Centro de Ciências Humanas-CCH

Departamento de Artes- DEART

COORDENAÇÃO DO CURSO DE LICENCIATURA EM TEATRO

\title{
JOGO DE TABULEIRO: UMA PROPOSTA DE AVALIAÇÃO NO ENSINO DE TEATRO NO ENSINO MÉDIO
}

Larissa Cutrim da Rocha

(UFMA; larissacutrimrocha@gmail.com)

Orientador(a): Prof. Ma Flávia Andresa O. de Menezes

\section{RESUMO}

A avaliação é uma etapa essencial para o processo de ensino e aprendizado no contexto formal e informal, servindo de base para reflexão da prática docente e posteriormente agindo de forma significativa no aprendizado do aluno, isso quando o professor lança mão dos resultados obtidos e propõe ações diretas onde percebe dificuldades ou até mesmo servindo para identificação de pontencialidades e então direcione sua prática para esses campos mais propícios para o aprendizado.

Em se falando do ensino do teatro, onde o seu fazer é de característica processual, no contexto escolar onde o interesse principal do professor não é a formação de atores, nem o resultado, “peça”, mas o processo que pode ser desencadeado pela prática teatral, a avaliação se apresenta neste quadro de forma desafiadora, requerendo instrumentos avaliativos que de fato somem com a aprendizagem e estejam contextualizados com o público atendido. Com isso, o grupo que compunha o Pibid Teatro no ano de 2015 elaborou um jogo de tabuleiro denominado “Gioco Dell’arte”, para servir como instrumento de avaliação dos alunos, após as aulas sobre Commédia Dell’arte.

A pesquisa visa analisar o jogo de tabuleiro: Gioco Dell'arte, como instrumento avaliativo no ensino da linguagem teatral no Ensino Médio. Para Jussara Hofmann a avaliação é essencial para a aprendizagem e deve ser bem elaborada para servir de acompanhamento do aprendizado do aluno bem como da prática do docente que pode refletir sobre suas ações com base nos resultados alcançados. 


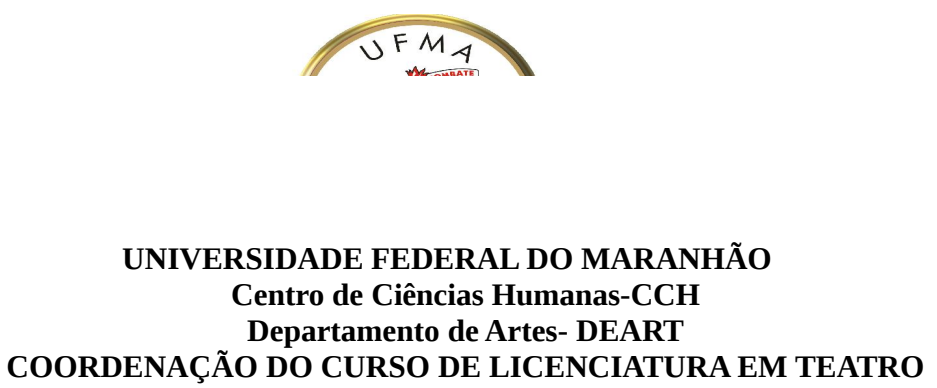

Encontramos o uso de protocolos de sessão, diário de bordo, círculo de discussão como instrumentos avaliativos no ensino do teatro (JAPIASSU, 2001) que estão no campo de avaliações não tradicionais, pois a prova escrita é a mais encontrada no contexto escolar, assim o jogo de tabuleiro entra neste campo de avaliação não tradicional. A análise segue segundo a ótica dos instrumentos do espetáculo (ROUBINE, 1998) encontrados nos elementos que compõe o jogo, bem como a conceituação destes segundo Patrice Pavis (2005). Chegando ao resultado da proposta do jogo ser um instrumento favorável a avaliação em diversos aspectos, da produção, apreciação artística bem como contextualização (BARBOSA, 2010).

Por fim todo material que adentra a sala de aula para somar com o processo de ensino e aprendizagem é bem vindo, quando este se mostra interessante ao aluno e ao mesmo tempo tem objetivos bem elaborados e são executados. 